positions. Here too, this is the case. Represented in the above table there are the relatively conservative, almost invariably scholarly Presbyterian, clergymen, such as Richard Baxter and the man who preached his funeral sermon (with a copy of that sermon) William Bates, along with the ecclesiastically and often doctrinally eccentric, frequently unlearned thinker-theologians such as John Bunyan and Thomas Delaune. Forbes, for instance, possessed a copy of Delaune's A Plea for the Non-conformists, for which the author was imprisoned in. Newgate prison where he together with his whole family died of general privation.

It is, of course, in the nature of a library to mimcor its ormer's general field of interest, but, within that field to represent the variety of opinions to which men could and did adhere. We can thus go only so far when we attempt to chart a man's mind by reference to his library. There is, however, an alternative explanation for our inability to reconcile to our total satisfaction the man's mind with his library. This lies in the almost inevitable tendency on the part of historians to employ more or less anachronistic labels to dispose of the otherwise impossible complexities of this subject. Nowhere does.this apply more than to the religious and ecclesiastical history of seventeenth century England where as I have already suggested, the labels "Puritan" and "Nonconformist" have been tried and found wanting: perhaps the same fate awaits the next layer of tags, "Presbyterian", "Independent" etc.

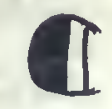

\title{
RECENT ACQUISITIONS AT THE NEWBERRY LIBRARY
}

Within the last few years The Newberry Library in Chicago has purchased collections of manuscripts, microfilms and printed books which will be of great interest to our readers working in Reformation studies. These acquisitions reflect the interest of Dr. John A. Tedeschi in the Italian Reformation and the role of the library as co-publisher of the Corpus Reformatorum Italicorum.l

An important recent acquisition are the nine volumes of "Castelvetro" manuscripts containing copies of extremely interesting official and diplomatic documents, letters of sovereigns, reports of ambassadors concerning court and state affairs (in the style of the famous Venetian relazioni), and contemporary first-hand accounts of the political and religious situations in several European countries, almost all from the second half of the sixteenth century. Many of the documents have never been published and the originals may no longer exist. The volume containing reports on France (thirteen texts). includes an account by a Florentine gentleman, Tommaso Sassetti, of the St. Bartholomew's day massacre in Paris and a Report on the siege of Paris (1590). This fascinating historical library was assembled under mysterious circumstances at Copenhagen in 1594 by a Modenese religious exile and man of letters, Giacopo Castelvetro (1546-d.1615). Many of the texts contain marginal comments in his hand.

1. One volume has appeared thus far in this series of critical editions of the writings of 16th century Italian Protestant Reformers: Camillo Renato, Opere, documenti e testimonianze, a cura di Antonio Rotondò (Florence: Sansoni; Chicago: The Newberry Library, 1968). 350 pp. (Corpus Reformatorum Italicorum diretto da Luigi Firpo e Giorgio Spini con la collaborazione di Antonio Rotondò e John A. Tedeschi). 
Another manuscript collection which recently came to the Newberry is the archive of the Parravicini, an influential feudal family of the Valtellina (an Alpine valley formed by the river Adda extending north-east of Milan), which during the Reformation belonged to the Grisons and served as an important haven for Italian Protestant exiles. The collection totals over 3,500 documents and manuscript books spanning the period from the mid-15th to the mid-19th century. Much of the material is of significance to social and economic historians, including as it does dowries wills, land contracts and extensive correspondence. Other documents concerm the Reformation, such as, for example, a list of Protestants living in the Valtellina early in the 17th century. This compilation may have been the blueprint for the bloody slaughter (Sacro Macello) of evangelicals which took place in 1620 and in which a certain Giovanni Maria Parravicini was one of the leading conspirators.

Much manuscript material concerned with the activity of the Inquisition in Italy has been obtained on microfilm and reproduced in Xerox. This includes the Indices (arranged alphabetically, chronologically and geographically) of the trials held before the Venetian Inquisition between 1541-1794. Numerous codices contain documents from the Archiginnasio: library in Bologna and illustrate abundantly the operation of the Bolognese Inquisition during the sixteenth century. In the group is the correspondence exchanged by the Holy Office in Rome and the provincial Inquisition from 1572 to 1594.2 They reveal the extent to which the local Inquisitor depended upon instructions from Rome, even in the most trivial matters. The letters discuss measures taken against the diffusion of Protestant ideas in the Bologna area, and against necromancers and relapsed Jews. They are also an important source for the study of the application in Italy of the regulations of the newly-founded Congregation of the Index. ${ }^{3}$ Another Bolognese document is the Libro de' Morti, dating from the second half of the 16th century. It includes the names of all individuals executed for crimes, religious and other. 4

Also available at Newberry are Xerox copies of Italian Inquisitorial documents located in libraries outside of Italy, a small part of the archival treasures taken from Rome during the Napoleonic period and never returned. The two principal collections in this category are the sentences issued by Roman and provincial Inquisitors between 1567-1603. They are especially valuable since the archive of the Inquisition in Rome is still closed to scholars and, in any case, the majority of trial records themselves have perished or been dispersed. The originals are now preserved at Trinity College Library, Dublin。5 Some years after Napoleon's fall they were obtained by the Duke of Manchester and eventually transferred to Ireland.

2. Bologna, Bibliotec Comunale dell' Archiginnasio; MSS. 1860, 1861.

3. Other Inquisitorial collections from the Archiginnasio available in Xerox at Nerberry are the "Consilia et vota in materia S。 Officii" (Ms。1859); "Atti diversi del S. Ufficio di Bologna" (Ms. 1877); "Atti e processi contro gli eretici" (Ms. 1927); "Bandi, decreti e sentenze del S。Ufficio" (Ms。1926)。

4. Bologna, Archiginnasio MS. 54.

5. MS. 1224, 1225, 1226, 1227, 1228. The Newberry has obtained Xeroxes only of those five volumes which concerm the sixteenth and very early 17 th centuries. The collection as a whole extends to the end of the l8th century. 
The second collection will make it possible to reconstruct, at least in part, the activity of the Florentine Inquisition. The Nevberry has acquired the microfilms of documents now preserved in the Bibliotheque Royale, Brussels。6 This collection, in four volumes, includes correspondence between the Inquisitors of Rome and Florence and various Inquisitorial decrees and proclamations of the 16-18th centuries regulating policy towards non-Catholic foreigners, Jews, prohibited books, etc.

Moving from Italy to France, the Newberry has acquired a block of 150 pamphlets to add to its already important collection of 16 th and 17 th century political and religious literature.? Among many interesting items here are a 1568 edition of the letters of Jeanne d'Albret (La Rochelle, B. Berton); an attack on Henri III, Les Sorceleries de Henri de Valois (1589); and funeral orations for François de Lorraine, Duc de Guise (by Jacques Le Hongre, given in March 1562); for Henry III (given by Claude de Privas de Morenne in August, 1595); and for Henri IV (by Jacques Suarez and Nicolas de Paris, June, 1610).

Each year The Newberry Library makes available for research in its collections a limited number of grants-in-aid (1-3 months) and year-long Junior Fellowships for graduate students who have reached the dissertation level.

7. A checklist of French political pamphlets, 1560-1644, in The Newberry Library, compiled by Doris Varner Welsh (Chicago, 1950); A second checklist of French political pamphlets, 1560-1653, in The Newberry Library, compiled by Doris Vamer Welsh (Chicago, 1955). The collection will be made available on microfilm in the near future by Bell \& Howell.

\section{NEW PLANS ... (continued from page 1)}

They will be aided by a Board of Advisors, made up of scholars at Toronto and also at other universities served by the bulletin. In this way it is hoped that research activities and resources at these universities will be more readily brought to the attention of the editors. The Board of Advisors is as follows: Thomas Caine, McMaster University; Beatrice Corrigan, Italian and Hispanic Studies, University of Toronto; Natalie Z. Davis, Department of History, University of Toronto; F. David Hoeniger, Department of English, Victoria University in the University of Toronto; Brayton Polka, Department of History, York University.

The present co-editors want to thank the contributors of articles over the past five years for their good-humoured help and especially to acknowledge the work of Germaine Warkentin, editorial assistant for R\&R. 